\title{
The Girl Talk Dilemma: Can Copyright LaW ACCOMmodate New Forms of SAMPLE-BaSed Music?
}

\author{
David Mongillo \\ Spring 2009 \\ Copyright (C) University of Pittsburgh School of Law \\ Journal of Technology Law and Policy
}




\section{INTRODUCTION}

On Gregg Gillis' laptop computer are thousands of files representing a vast slice of 20th and 21 st century popular music. ${ }^{1}$ His digital music collection is similar to that of many music consumers: it spans a wide variety of genres and runs from the obscure to the mainstream. But Gillis is different from most music consumers in that he uses computer software to cut his digital music files into audio snippets, or samples, and then piece them together into song collages. ${ }^{2}$ Gregg Gillis is Girl Talk, a recording artist on the Illegal Art label whose music has made yearend best music lists in Time Magazine, ${ }^{3}$ Rolling Stone, ${ }^{4}$ Blender ${ }^{5}$ and Pitchforkmedia.com. ${ }^{6}$ Girl Talk has developed a strong following throughout the United States and has toured throughout Europe and Australia. ${ }^{7}$ A PC user, he was recently featured in one of the "I'm a PC" ads for Microsoft. ${ }^{8}$ But while Girl Talk has been successful, Gillis adds almost no original musical content to his recordings. Although he often alters the speed or pitch of his samples, or loops them in a continuous pattern, he does not sing or rap over his creations. Furthermore, Gillis has

\footnotetext{
${ }^{1}$ Girl Talk, PITCHFORK, Aug. 30, 2006, http://pitchfork.com/features/interviews/6415-girl-talk/.

${ }^{2}$ Robert Levine, Steal this Hook? DJ Skirts Copyright Law, N.Y. TIMES, Aug. 7, 2008, at E1, available at http://www.nytimes.com/2008/08/07/arts/music/07girl.html.

${ }^{3}$ Time ranked Girl Talk's album "Feed the Animals" number four on the top 10 albums of 2008. Josh Tyrangiel, Top Ten Albums, TIME, available at http://www.time.com/time/specials/2008/top10/article/0,30583,1855948_1864324_1864335,00.html. Feed the Animals by Girl Talk").

${ }^{4}$ Rolling Stone ranked Girl Talk's album "Feed the Animals" number twenty-four on its list of the 50 Best Albums of 2008. The 50 Best Albums of 2008, ROLLING STONE, available at http://www.rollingstone.com/news/story/24958695/the_50_best_albums_of_2008/31.

5 Blender name Girl Talk's album "Feed the Animals" the second best recording of 2008. The 33 Best Albums of 2008, BLENDER, Nov. 11, 2008, available at http://www.blender.com/articles/default.aspx ?key=45690\&pg=0. ${ }^{6}$ Girl Talk's album "Night Ripper" ranked number thirty-four in 2006. The Top 50 Albums of 2006, PITCHFORK, Dec. 19, 2006, http://pitchfork.com/features/staff-lists/6510-top-50-albums-of-2006/2/. "Feed the Animals" ranked number thirty-five in 2008. The 50 Best Albums of 2008, PITCHFORK, Dec. 19, 2008, http://pitchfork.com/features/staff-lists/7573-the-50-best-albums-of-2008/2/.

${ }^{7}$ Between Feb. 52009 and March 28, 2009 Girl Talk is scheduled to play in twenty-four cities, including Sydney, Miami, London, Barcelona, Paris and Stockholm. MySpace, www.Myspace.com/girltalk (last visited Feb. 10, 2009).

${ }^{8}$ Rich Coleman, Gregg Gillis/Girl Talk Interview, ThE DAILy COLLEGIAN OnLine, Dec. 11, 2008, available at http://www.collegian.psu.edu/venues/2008/12/11/gregg_gillisgirl_talk_intervie.aspx.
} 
never sought licenses or authorization for any of the samples he uses. ${ }^{9}$ For instance, his latest album, "Feed the Animals," includes over 300 unauthorized samples ${ }^{10}$ of artists ranging from Lil Wayne to Radiohead to Metallica to Kenny Loggins.

Although his music has been the subject of controversy and debate, Girl Talk has not been sued for copyright infringement. Some hypothesize that the major labels have not brought action for fear of losing in court and creating a new precedent more amenable to artists like Girl Talk. ${ }^{11}$ If an artist does decide to take legal action, however, Gillis has stated that he believes the fair use defense to copyright infringement applies to his music. ${ }^{12}$

This note argues that the fair use defense to copyright infringement should be interpreted to apply to Girl Talk's music. Superseding the current fair use doctrine with a bright-line license system, as some have suggested, would stifle innovation. In part I, I will discuss the current precedent related to copyright infringement and fair use in the context of audio sampling. In part II, I will argue that Girl Talk's music raises distinct issues not contemplated by existing precedent, and that the fair use defense should be available to Girl Talk. Finally, in part III, I will lay out possible solutions to the problems Girl Talk's music presents under the current fair use doctrine, arguing that an expansion of the fair use doctrine to protect artists like Girl Talk is the best alternative.

\section{PART I}

\footnotetext{
${ }^{9}$ Levine, supra note 2 .

${ }^{10}$ Illegal Art, http://www.illegal-art.net/shop (last visited Mar. 11, 2009) (roll over the "Feed the Animals" hyperlink).

${ }^{11}$ Posting of David Bollier to onthecommons.org, Is Fair Use Regaining Its Mojo?, http://onthecommons.org/content.php?id=2148 (Aug. 10, 2008).

${ }^{12}$ Levine, supra note 2.
} 
Sampling involves the appropriation of previously recorded audio material in order to create a new audio work. Musicians have always used the previous work of other artists as inspiration. For example, Paul McCartney admitted to cribbing a Chuck Berry bass riff for the Beatles hit, "I Saw Her Standing There." ${ }^{\text {13 }}$ Sampling, however, does not occur when a musician uses instruments to recreate a previous recording or composition. Sampling is when one incorporates a prior soundrecording into a new work. ${ }^{14}$ Although there are examples of sampling from as early as the $1940 \mathrm{~s}^{15}$, modern sampling grew out of the hip-hop movement of the late seventies and early eighties. ${ }^{16}$ During this time, advances in audio technology made sampling easier and it became more widespread. ${ }^{17}$ Although some artists obtained licenses for their samples, some did not. As hip hop recordings featuring sampled material became more prominent, copyright owners began to take legal action against sampling artists. For example, in 1990, Vanilla Ice settled out of court after copyright holders brought action based on his use of the song "Under Pressure" (made famous by Queen and David Bowie) in his hit "Ice, Ice Baby." 18

\section{A. GRAND UPRIGHT}

In 1991 the U.S. Court for the Southern District of New York set a clear precedent in favor of copyright holders, deciding Grand Upright Music, Ltd. v. Warner Bros. Records, which marked a dramatic shift in the way the music industry approached sampling. ${ }^{19}$ The plaintiff in

\footnotetext{
${ }^{13}$ Congressman Mike Doyle (D-Pa.) mentioned this incident during a speech in support of copyright protection for artists like Girl Talk. Press Release, Congressman Mike Doyle, Congressman Doyle Calls for Reevaluation of Copyright Laws (Mar. 7, 2007) (on file with author), available at http://doyle.house.gov/newsrel/070307.htm. ${ }^{14}$ See Newton v. Diamond, 388 F.3d 1189, 1192 (9th Cir. 2003), cert. denied, 545 U.S. 1114 (2005).

${ }^{15}$ David J. Moser, Music Copyright For the New Millennium 62 (ProMusic Press 2002).

${ }^{16} \mathrm{Id}$.

${ }^{17} \mathrm{Id}$.

${ }^{18} I d$.

19780 F. Supp. 182.
} 
that case claimed copyright infringement under 17 U.S.C. $§ 501$ against rapper Biz Markie. Biz Markie's song “Alone Again” used samples of the three-word chorus and some other instrumentation from Gilbert O’Sullivan's song “Alone Again Naturally.” The court granted a preliminary injunction against Biz Markie, rejecting his defense that sampling was widespread in rap music and therefore he should not be held liable for something everyone was doing. ${ }^{20} \mathrm{The}^{2}$ court's opinion began with a quotation of the Seventh Commandment, "thou shalt not steal,"21 and suggested that the U.S. Attorney's office pursue criminal prosecution for violations of 17 U.S.C. $§ 506(a)$ and 18 U.S.C. $§ 2319 .^{22}$

After the Grand Upright opinion, labels became more conservative, with stricter requirements that any songs containing sampled material be fully licensed before distribution. ${ }^{23}$ During the late eighties, before the Grand Upright opinion, several critically acclaimed and commercially successful albums were created using large numbers of unlicensed samples. Some examples include De La Soul's “Three Feet High and Rising,"24 The Beastie Boys' "Paul's Boutique"25 and Public Enemy's "It Takes a Nation of Millions to Hold us Back."26 Many believe that if an opinion like Grand Upright had come along sooner, these influential and

\footnotetext{
${ }^{20}$ Grand Upright, 780 F. Supp. at 185, n.2.

${ }^{21} I d$. at 183 .

${ }^{22} I d$. at 185 .

${ }^{23}$ MOSER, supra note 15 , at 63 . Generally a copyrighted musical work will be protected by both a sound recording copyright under 17 U.S.C. 114(b) (protecting the specific recorded version of the work) and a musical composition copyright under 17 U.S.C. $\S 102$ (a)(2) (protecting the underlying composition). Clearance of an audio sample will generally require the sampling artist to pay for both a sound recording license and a musical composition license under 17 U.S.C. § 106(2). See Bridgeport Music, Inc. v. Dimension Films, 410 F.3d 792, 800 (6th Cir. 2005).

${ }^{24}$ Dorian Lynskey, A Little Bit of This, A Little Bit of That, The GuARDiAn, Oct. 24, 2008, at 5.

${ }^{25} I d$.

${ }^{26}$ Kembrew McLeod, How Copyright Law Changed Hip Hop: An Interview With Public Enemy's Chuck D and Hank Shocklee, STAY FREE!, Fall 2002, http://www.stayfreemagazine.org/archives/20/public_enemy.html
} 
groundbreaking albums would never have been made because of the cost associated with clearing sampled material. $^{27}$

While the Grand Upright opinion had a significant impact on licensing practices in the recording industry, it has had less impact on courts, which have, as of January 1, 2009, collectively cited to the case only 10 times $^{28}$ The judge in Grand Upright offered no citations to legal precedent explaining his opinion and the defense failed to raise relevant arguments, such as fair use.

\section{B. FAIR USE}

The copyright clause of the Constitution creates a system whereby a copyright holder enjoys a limited monopoly on the use of his copyrighted material. ${ }^{29} \mathrm{~A}$ copyright holder can bring a claim for copyright infringement under 17 U.S.C. $\S 501$. The policy behind the copyright clause is to encourage creativity, based on the theory that artists will be more willing to create when they know their work will be protected from infringement. ${ }^{30}$ However, the framers of the Constitution recognized that an unlimited monopoly on copyright was not in the public's best interest, and therefore included the provision that copyrights should last for "limited Times." 31

\footnotetext{
${ }^{27}$ Public Enemy producer Hank Shocklee stated that if "It Takes a Nation of Millions to Hold us Back" were made later in time, it may not have been impossible to clear and pay for the licenses involved but it would have been "very, very costly." He went on to explain that on Public Enemy's subsequent album, "Fear of a Black Planet," as music publishers began enforcing their copyrights, the group was forced to rely more heavily on conventional instruments. This contributed to a "softer" sound on the later record. Id. See also Girl Talk and the Sample License Clearance Process, http://futureofmusiccoalition.blogspot.com/2008/08/girl-talk-and-sample-license-clearance.html (Aug. 27, 2008, 11:43 EST) ("Given the cumulative effect of multiple expensive samples, one can see why the sample-laden albums like the Beastie Boys' Paul's Boutique or Public Enemy's It Takes a Nation of Millions couldn't be made today").

28 LEXIS Shepard's Report for Grand Upright (Jan. 1, 2009).

${ }^{29}$ U.S. CONST. art. I, § 8, cl. 8.

${ }^{30}$ Pierre N. Leval, Toward a Fair Use Standard, 103 HARV. L. REV. 1105, 1107-08 (1990).

${ }^{31}$ U.S. CONST. art. I, § 8, cl. 8.
} 
One of the strongest limitations on the copyright monopoly is the fair use doctrine. The fair use doctrine was adopted by Congress in the Copyright Act of 1976, and codified at 17 U.S.C. $§ 107$. When it is uncontested that the defendant has indeed used copyrighted work, the fair use defense may apply to overcome an infringement claim. Fair use is meant to cut against the limited monopolies set up by the copyright clause, allowing the public to use copyrighted material in certain ways that will enrich society and promote progress. Fair use, therefore, is guided by the same policy considerations as the Constitution's copyright clause: "to promote the Progress of Science and the useful Arts." 32

Section 107 reads:

Notwithstanding the provisions of sections 106 and 106A, the fair use of a copyrighted work, including such use by reproduction in copies or phonorecords or by any other means specified by that section, for purposes such as criticism, comment, news reporting, teaching (including multiple copies for classroom use), scholarship, or research, is not an infringement of copyright. In determining whether the use made of a work in any particular case is a fair use the factors to be considered shall include-

(1)the purpose and character of the use, including whether such use is of a commercial nature or is for nonprofit educational purposes;

(2)the nature of the copyrighted work;

(3)the amount and substantiality of the portion used in relation to the copyrighted work as a whole; and

(4)the effect of the use upon the potential market for or value of the copyrighted work.

The fact that a work is unpublished shall not itself bar a finding of fair use if such finding is made upon consideration of all the above factors.

${ }^{32}$ U.S. CONST. art. I, § 8, cl. 8. 
While the code mentions several specific uses that should be protected ("criticism, ${ }^{33}$ comment, news reporting, teaching...”) this list is not exclusive. ${ }^{34}$ In Campbell v. Acuff-Rose, for example, the U.S. Supreme Court extended the protection of fair use to parody. ${ }^{35}$ The Court in Campbell further explained that fair use should be analyzed on a case-by-case basis, using the four $§ 107$ factors. ${ }^{36}$ The four factors should not be isolated from each other but should be taken together "in light of the purposes of copyright." 37

\section{PURPOSE AND CHARACTER OF THE USE}

The courts have created several balancing tests to assist in determining whether the character of the use argues for or against fair use. For example, if the work is commercial rather than non-profit, then the work is less likely to be classified as a fair use. ${ }^{38}$ However, just because a work is commercial does not mean it cannot be protected. ${ }^{39}$

Another balance the courts have considered is that between transformative and nontransformative works. ${ }^{40}$ The Supreme Court in Campbell explained that a transformative work "adds something new, with a further purpose or different character, altering the first with new expression, meaning, or message."41 A non-transformative work, on the other hand, "merely

\footnotetext{
${ }^{33}$ In a recent decision from the United States District Court for the Southern District of New York, the court held the use of 15 seconds of John Lennon's song "Imagine" in a documentary about intelligent design, to be a fair use criticism. The court found that the movie criticized the atheist perspective of the song, which asks listeners to imagine a world with no religion. Lennon v. Premise Media Corp., 556 F.Supp. 2d 310, 322-23 (S.D.N.Y. 2008).

${ }^{34}$ Campbell v. Acuff-Rose Music, 510 U.S. 569, 576-77 (1994).

${ }^{35} \mathrm{Id}$. at 579.

${ }^{36} \mathrm{Id}$. at 577 .

${ }^{37} \mathrm{Id}$. at 579 .

${ }^{38} \mathrm{Id}$.

${ }^{39} \mathrm{Id}$. at 584 .

${ }^{40} I d$. at 579 .

${ }^{41} I d$.
} 
'supersedes the objects' of the original creation., ${ }^{, 2}$ However, even when a work is nontransformative, it may still be granted fair use protection based on consideration of all four fair use factors. ${ }^{43}$

Parodies are one type of work that has been found to be transformative. ${ }^{44}$ The Court distinguished a parody from a satire, explaining that a parody ridicules or critiques the particular expression of the appropriated prior work, while satire uses the prior work to make a more general comment on the foibles of society as a whole. ${ }^{45}$ For example, the rap group 2 Live Crew, in the Campbell case, was found to have created a valid parody of Roy Orbison's "Oh,Pretty Woman" by sampling the instrumentation from the song but changing the lyrics to point out the dated, unrealistic viewpoint of the original. ${ }^{46}$ In a series of suits against artist Jeff Koons, on the other hand, courts have found no parody, but satire, in pieces of art that appropriated copyrighted material to make broad statements about our cultural consciousness. ${ }^{47}$

The first two of these decisions went against artist Jeff Koons and seemed to stand for the proposition that satire is not transformative. ${ }^{48}$ But the third decision, Blanch v. Koons, expanded the realm of fair use in the appropriation-art arena, finding that a satiric work may be protected

\footnotetext{
${ }^{42}$ Id. (quoting Folsom v. Marsh, 9 F. Cas. 342, 348 (C.C.D. Mass. 1841) (No. 4,901)).

${ }^{43}$ Reproduction of copyrighted material for classroom use is one example where there is no transformativeness but fair use nonetheless. Id. at n.11.

${ }^{44} I d$.

${ }^{45} I d$. at $580-81$.

${ }^{46} I d$. at 583 .

${ }^{47}$ Blanch v. Koons, 467 F.3d 244, 255 (2d Cir. 2006) (finding that a representation of a copyrighted photograph of female legs was a satire because its use was meant to comment generally on the aesthetic impact of mass media);Rogers v. Koons, 960 F.2d 301, 310 (2d Cir. 1992) (finding that a sculpture representing a copyrighted photograph of a litter of puppies was a satire because it was meant to criticize banal aspects of society); United Features Syndicate v. Koons, 817 F. Supp. 370, 383-84 (S.D.N.Y. 1993) (finding that a sculpture representing the cartoon dog "Odie" from the comic strip "Garfield" was not a parody because was not meant to ridicule Odie specifically).

${ }^{48}$ See Rogers, 960 F.2d at 310; see also United Features Syndicate, 817 F. Supp. at 383-84.
} 
under fair use. ${ }^{49}$ In Blanch the U.S. Court of Appeals for the Second Circuit found that Koons' use of copyrighted material in a collage painting was transformative. ${ }^{50}$ The painting, "Niagara," recreated a photograph of a woman's feet, taken by plaintiff and professional photographer Andrea Blanch. ${ }^{51}$ The photograph was originally used in an advertisement for Gucci sandals, which Koons clipped out of a magazine, scanned into digital format, then incorporated into his work. ${ }^{52}$ Koons explained that the photograph represented a "particular type of woman frequently presented in advertising. ${ }^{, 53} \mathrm{He}$ considered this typicality necessary "to further his purpose of commenting on "commercial images...in our consumer culture.",54 Koons further explained that he wanted "the viewer to think about his/her personal experience with these objects, products, and images and at the same time gain new insight into how these affect our lives." ${ }^{55}$ The court contrasted Koons' goal with Blanch's goal in composing and taking the original photograph ("to get...more of a sexuality to the photographs" ${ }^{\text {"56 }}$ ) and found that Koons' work was transformative. According to the court, if Koons had argued that his work was transformative simply because the original work was a photograph and his work was a painting, transformativeness would have been lacking. ${ }^{57}$ Instead, the court found that the goals of the two works were divergent, that Koons went beyond mere repackaging of the original, and that he used "Blanch's image as fodder for his commentary on the social and aesthetic consequences of mass media., ${ }^{, 58}$

\section{NATURE OF THE COPYRIGHTED WORK}

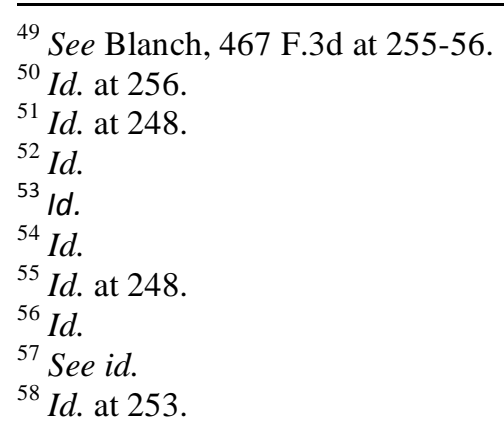


The second fair use factor, $\S 107(2)$, requires an examination of the work that has been infringed. As the Supreme Court in Campbell explained, "[t]his factor calls for recognition that some works are closer to the core of intended copyright protection than others, with the consequence that fair use is more difficult to establish when the former works are copied." ${ }^{, 59}$ So, for example, a fictional work will receive greater copyright protection than a factual work and fair use will be more difficult to find when a fictional work has been infringed. ${ }^{60}$ Similarly, a creative work will receive greater protection than a factual compilation. ${ }^{61}$ In the parody context, however, this factor offers little help in distinguishing works that are protected by fair use from those that are not protected. ${ }^{62}$ This is because "parodies almost invariably copy publicly known, expressive works."

\section{THE AMOUNT AND SUBSTANTIALITY OF THE PORTION USED}

The main question in deciding the third factor of the fair use test, found in $\S 107(4)$, is whether the user of copyrighted material took a reasonable amount in relation to the purpose of the copying. ${ }^{64}$ It is therefore important to consider the "persuasiveness" of the alleged infringer's underlying purpose in creating his or her work. ${ }^{65}$ This factor is tied to factor number one, the purpose of the work, because if the purpose is infringing, then no amount of taking will be allowed. Similarly, if there is a valid purpose, the taking still may be too great if it goes beyond

\footnotetext{
${ }^{59} 510$ U.S. at 586.

${ }^{60}$ Suntrust Bank v. Houghton Mifflin Co., 268 F.3d 1257, 1271 (11th Cir. 2001); Stewart v. Abend, 495 U.S. 207 , 237-38 (1990); Campbell, 510 U.S. at 586.

${ }^{61}$ See Feist Publ'ns, Inc. v. Rural Tel. Serv. Co., 499 U.S. 340, 349 (1991)(“the copyright in a factual compilation is thin").

${ }^{62}$ Campbell, 510 U.S. at 586.

${ }^{63} \mathrm{Id}$.

${ }^{64} \mathrm{Id}$.

${ }^{65}$ Campbell, 510 U.S. at 586.
} 
what is reasonable for that purpose. ${ }^{66}$ For example, in Harper \& Row Publishers v. Nation Enterprises, a newspaper published some of the most significant portions of an unpublished autobiography of Gerald Ford, which the court found was unnecessary in light of the newspaper's purpose (news reporting). ${ }^{67}$ Even though the taking in Harper \& Row was quantitatively small in relation to the entire work (300 words from a book-length autobiography), the Court explained that the taking was nonetheless substantial because it comprised " "essentially the heart of the book."

This "heart of the [work]" test emphasizes that the quality of the borrowed work is more important to this fair use factor than its quantity or length. ${ }^{69}$ The Court in Campbell recognized, however, that a parody will often need to take some of the most substantial and recognizable elements of the original in order to be a successful parody. ${ }^{70}$ As a result, parodies enjoy a higher threshold under this factor, and may take the "heart of a work" if it is necessary to "conjure up the original" work in the mind of the audience. ${ }^{71}$

Additionally, a small or unrecognizable taking may be considered de minimus, and noninfringing because it is so insubstantial. ${ }^{72} \mathrm{~A}$ de minimus argument is a complete defense to copyright infringement and application of the fair use doctrine is unnecessary if a de minimus taking is found. ${ }^{73}$ In Newton, the court appropriated the de minimus test from Fisher v. Dees and applied it to the audio sampling context. If the copyrighted sample would not be recognizable to

${ }^{66}$ Id. at 586-87.

${ }^{67}$ See 471 U.S. 539, 564-66 (1985).

${ }^{68} \mathrm{Id}$. at 564-65 (quoting the district court opinion, 557 F. Supp. 1067, 1072 (S.D.N.Y. 1983)).

${ }^{69}$ See id. .

70510 U.S. at 588.

${ }^{71}$ Id.; see, e.g., Fisher v. Dees, 794 F.2d 432, 438-39 (9th Cir. 1986) (quoting Elsmere);Elsmere Music, Inc. v. National Broadcasting, Co., 623 F.2d 252, 253, n.1 (2d. Cir. 1980) (a work may take more than would minimally conjure up the original, if necessary for the parody's humorous effect. "A parody is entitled at least to 'conjure up' the original").

${ }^{72}$ See Newton, 388 F.3d at 1192-93.

${ }^{73} I d$. 
a fan of the original artist's work, then there is no infringement according to the Newton test. ${ }^{74}$

However, the courts in both Newton and Fisher considered the de minimus doctrine only in relation to infringement of a musical composition copyright. ${ }^{75}$ The court in Bridgeport Music,

Inc. v. Dimension Films, however, found that the de minimus defense does not apply when a sound recording copyright has been infringed by a sampling artist. ${ }^{76}$ The court put forth brightline rule: "get a license or do not sample.",77 This rule, although predictable and easy to understand, obliterates the de minimus defense to copyright infringement in the sampling context. The Bridgeport rule may also obliterate fair use in the sampling context because the rule leaves no room for exceptions when unlicensed samples should be allowed. ${ }^{78}$

\section{THE EFFECT OF THE USE UPON THE POTENTIAL MARKET VALUE OF THE}

\section{COPYRIGHTED WORK}

There are three general components to the fourth fair use factor, $\S 107(4)$, as identified in Campbell: (1) [t]he impact of the "particular actions of the alleged infringer" on the market for the original; (2) "[w]hether unrestricted and widespread conduct of the sort engaged in by the defendant" would harm the market for the original; and (3) harm to the market for derivate works of the original. ${ }^{79}$ While harm to the market is relatively clear-cut when the defendant's use is non-transformative and commercial, ${ }^{80}$ a transformative work is less likely to cause harm and the

\footnotetext{
${ }^{74}$ Id. at 1193; see also Fisher, 794 F.2d at 434 n.2.

${ }^{75}$ Newton, 388 F.3d at 1193; see also Fisher, 794 F.2d at 434.

${ }^{76} 410$ F.3d 792, 798-802 (6th Cir. 2005); See supra note 23 for an explanation of the difference between a musical composition copyright and a sound recording copyright.

${ }^{77}$ Bridgeport Music, Inc., 410 F.3dat 801.

${ }^{78}$ See Joshua Crum, The Day the (Digital) Music Died: Bridgeport, Sampling Infringement, and a Proposed Middle Ground, 2008 B.Y.U. L. Rev. 943, 960-64 (2008) (arguing that the Bridgeport rule is incompatible with fair use).

${ }^{79}$ Campbell, 510 U.S. at 590.

${ }^{80}$ Id. at 591; see also Sony Corp. of Am. v. Universal Studios, Inc., 464 U.S. 417, 451 (1984) (considering the copyright implications of video cassette recording machines and explained that if video cassette copies of copyrighted material are made for commercial use, there is a presumption of market harm).
} 
analysis is more complicated. ${ }^{81}$ Also, in the parody context, some harm to the market that is attributable to the nature of parody (similar to a drop in ticket sales after a scathing theater review) should be tolerated. ${ }^{82}$

\section{PART II}

Although some have called him a DJ or a "mash-up" artist, Gillis considers himself a musician whose instrument is the laptop. ${ }^{83}$ In distancing himself and his music from the labels of "DJ" and "mash-up," Gillis seems to imply that his music is something new. If a court is willing to accept that Girl Talk represents a new form of music, then this may loosen the binds of past sampling decisions and may help to show transformativeness. Therefore, in order to accurately apply fair use precedent to Girl Talk, it is important to distinguish Girl Talk, if possible, from other sampling-based forms of music.

First, Girl Talk albums contain far more sampled material per song than even the most sample-heavy hip hop albums. Second, a hip hop song will feature original vocals (rapping) and, usually, original drum-beats or other instrumentation. Gillis does not rap over his compositions and provides little, if any, original instrumentation in his songs. In hip hop, a sample will typically be used to "add something to the new recording," such as a memorable riff or refrain. ${ }^{84}$ With Girl Talk, however, the samples don't simply add something to the new song - the samples are the songs. In this respect, Girl Talk's music is dissimilar to sampling-based forms of music such as hip hop, and more similar to what is known as "mash-up."

\footnotetext{
${ }^{81}$ Campbell, 510 U.S. at 591.

${ }^{82}$ Id. at 591-92.

${ }^{83}$ Coleman, supra note 8.

${ }^{84}$ See Bridgeport, 410 F.3d at 802.
} 
A mash-up is a piece of music that layers portions of two or more previously recorded songs over one another, often with comic or novel effect. ${ }^{85}$ From a technical standpoint, Girl Talk's music fits neatly within the definition of a mash-up. However, most mash-ups use far fewer samples than Girl Talk does. A typical mashup will consist of the vocals of one song layered over the instrumentation from another song. ${ }^{86}$ Because of the proliferation of these types of lighthearted mixes, the term "mash-up" has taken on an air of gimmickry. ${ }^{87}$ There are many examples of more complex mash-up type projects, however. In 1985 innovator John Oswald created "plunderphonics," a style of sampling that takes well-known songs and distorts them with a variety of audio effects. ${ }^{88}$ In 1983 Steve Stein, known as Steinski, created a hip-hip collage of unlicensed samples, including clips of "Little Richard, Grandmaster Flash, Humphrey Bogart and former New York mayor Fiorello La Guardia." ${ }^{89}$ Producer Danger Mouse gained notoriety and sparked controversy when he created "The Grey Album," a full-length album that mashed together songs from Jay-Z's Black Album with songs from The Beatles' White Album. ${ }^{90}$ In some ways, it is difficult to distinguish Girl Talk from these more creative sampling projects that come under the rubric of "mash-up." However, one factor distinguishes Girl Talk from almost all other current mash-up projects: Girl Talk's music is sold commercially and samples unabashedly from Top 40 artists. $^{91}$

\footnotetext{
${ }^{85}$ Pete Rojas, Bootleg Culture, SALON, Aug. 1, 2002, http://archive.salon.com/tech/feature/2002/08/01/bootlegs/. ${ }^{86} I d$.

${ }^{87}$ See Aaron Power, 15 Megabytes of Fame: A Fair Use Defense For Mash-ups as DJ Culture Reaches Its Postmodern Limit, 35 Sw. U. L. REV. 577, 582 (2007) ("Some critics have written off [mash-up] as a mere 'gimmick'....').

${ }^{88}$ Lynskey, supra note 24.

${ }^{89}$ Id.

${ }^{90} \mathrm{Id}$.

${ }^{91}$ Although some other current artists have sampled Top 40 artists (for example, DangerMouse) and some other artists are selling albums containing unlicensed samples (for example, DJ Shadow) no other artists of Girl Talk's commercial profile use as many unlicensed samples of Top 40 artists. DangerMouse distributed "The Grey Album" for free and DJ Shadow samples exclusively from obscure, non-Top 40 artists. Lynskey, supra note 24.
} 
Due to its dissimilarity to sampling-based music such as hip hop, the sheer number of songs Girl Talk samples, and the fact that the songs are sold commercially, Girl Talk presents a distinct type of music that does not neatly fit within precedent or within traditional music genres. In the event a copyright holder sues Girl Talk for copyright infringement, the court must face the tension between fostering this type of music so that society is enriched, and ensuring that copyright holders are protected.

\section{PART III}

There are several possible solutions to the copyright issues presented by Girl Talk's music. In the following section I will evaluate some of these solutions, keeping in mind the goal of copyright: "to promote the Progress of Science and the useful Arts." then, will serve a dual role, protecting valid copyright interests (so that artists are not discouraged from creating) while allowing certain culturally-enriching uses of copyrighted material.

\section{A. NON-FAIR USE SOLUTIONS}

The main criticism of the current fair use doctrine is that it is unpredictable. Because fair use employs such a wide variety of balancing tests, critics argue, it is hard to gauge what will constitute fair use and what will not. These kinds of arguments have come from those in favor of

\footnotetext{
${ }^{92}$ U.S. CONST. art. I, § 8, cl. 8.
} 
greater freedom for sampling artists ${ }^{93}$ and those in favor of greater protection for copyright holders. $^{94}$

The Bridgeport decision, with its "get a license or do not sample" rule, came down firmly in favor of greater protection for copyright holders. ${ }^{95}$ The value of a bright line rule in this area, as the Bridgeport court pointed out, is its predictability. ${ }^{96}$ The rule, applied uniformly, would make copyright violations easy to spot, and would prod sampling artists, who would have previously relied on fair use or the de minimus defense, to seek out licenses. The downside of this rule, of course, is that it would limit creativity. Sampling would most likely decline and many creative uses would not occur. Girl Talk's style of music would almost certainly die out under this type of system. With victory assured, certain copyright holders would probably not hesitate to bring action against Girl Talk. Gillis would be forced to seek out and pay for hundreds of licenses per album, at whatever price the copyright holders would demand. The court in Bridgeport argued that market pressures would keep sample prices reasonable. ${ }^{97}$ However, nothing would stop copyright holders who object to Girl Talk's use from either charging exorbitant license fees or simply refusing to license their songs. However, even assuming that market pressures would keep sampling prices reasonable for the purposes of most sampling artists, Girl Talk's music would still be impossible to create. Girl Talk presents a special case because he samples far more copyrighted material than most other sampling artists. As a result, sampling fees that would be reasonable for an artist who uses one or two samples per song would

\footnotetext{
${ }^{93}$ Alex Kozinski, What's So Fair About Fair Use? 64 J. COPYRIGHT SOC'Y OF THE U.S. 513, 515 (1999)(“when it comes to derivative works, fair use doctrine is a red herring and we should just dump it") available at http://notabug.com/kozinski/fairuse.

${ }^{94}$ Christopher D. Abramson, Digital Sampling and the Recording Musician: A Proposal for Legislative Protection, 74 N.Y.U.L. REV. 1660, 1671 (1999)("the [fair use] doctrine is vague").

${ }^{95}$ Bridgeport Music, Inc. v. Dimension Films, 410 F.3d 729, 801 (6th Cir. 2005).

${ }^{96} I d$. at 801.

${ }^{97} I d$.
} 
be unreasonable for Girl Talk, who uses twenty to thirty samples per song. Therefore, any attempt to pay for licenses on a per-sample basis would probably be cost-prohibitive. Even if Girl Talk could pay for the required licenses, however, the mere administrative process of clearing every sample would be a practically insurmountable barrier. A piece of copyrighted music is generally protected by both a composition copyright and sound recording copyright, which are often owned by separate parties. Therefore, to clear the 300-plus samples on "Feed the Animals" Gillis and his label would have been forced to hunt down the owners of over 600 separate copyrights. ${ }^{98}$ Assuming all the owners could be located, Gillis and his label would then have had to undergo separate negotiations with each owner. The time and money required to pursue the licenses for "Feed the Animals" would have "likely...sunk the project.",99

The court in Bridgeport addressed the concerns about its bright-line test by suggesting that the record industry "fix" licensing fees for sampling, ensuring that samplers are efficiently charged a reasonable amount. ${ }^{100}$ Some have suggested that Congress should enact a blanket license system, similar to the system currently used for song performance rights, to strike a fair balance between the rights of copyright holders and the interests of sampling artists. ${ }^{101}$ Licensing associations such as BMI and ASCAP, which charge radio stations and public establishments such as bars, restaurants and hotels yearly fees for the right to transmit and perform copyrighted

\footnotetext{
${ }^{98}$ Future of Music Coalition Blog, http://futureofmusiccoalition.blogspot.com/2008/08/girl-talk-and-sample-licenseclearance.html (Aug. 27, 2008, 11:43 EST).

${ }^{99} I d$.

${ }^{100}$ Bridgeport, 410 F.3d at 804.

${ }^{101}$ See Crum, supra note 78, at 964; see also Lawrence Lessig, In Defense of Piracy, WALL STREET JOURNAL, Oct. 11, 2008, at W3, available at http://online.wsj.com/article/SB122367645363324303.html (arguing for creative alternatives to the current system for compensating copyright holders, and mentioning blanket licensing specifically).
} 
music, currently employ the blanket license model. ${ }^{102}$ Establishments, for example, pay different rates based on their type of use, frequency of use, and the size of establishment. ${ }^{103}$ The money that the licensing associations acquire from fees is then distributed as royalties to participating artists. ${ }^{104}$ Congress may be able to create blanket sampling licenses under which sampling artists pay a set fee for each sample they use, based on categories such as the length of the sample and the popularity of the original artist. ${ }^{105}$ Provided the rates are reasonable, a blanket sampling license would bypass the administrative and economic obstacles set up by the current licensing system, offering a theoretically viable solution for artists such as Girl Talk.

There are, however, some practical problems with a blanket licensing system which make it an unrealistic alternative to the current system. Two possible arguments against a blanket license system are that (1) copyright holders will receive less money than under the current system, and (2)copyright holders will have less control over the use of their copyrighted material. The argument that copyright holders will receive less money under a blanket license system is based on the fact that sampling artists will most likely pay less per sample under a blanket license system than under the current system, and therefore less money will flow to the copyright holders. If a blanket license system is designed to be able to accommodate artists like Girl Talk, for whom it would be cost prohibitive to acquire the requisite licenses under the current system, then the system must by design lower the amount such artists pay per sample. However, a blanket license system offering reasonable sampling fees, in tandem with the bright line Bridgeport rule, would prompt many artists to stop using copyrighted samples without paying for

\footnotetext{
${ }^{102}$ See BMI Licensing, Types of Copyright, http://www.bmi.com/licensing/entry/533606 (last visited Mar. 14, 2009).

${ }^{103}$ See BMI, Music License for Eating and Drinking Establishment, http://www.bmi.com/forms/licensing/gl/ede.pdf (last visited Mar. 14, 2009).

${ }_{104}$ BMI Licensing, General FAQS, http://www.bmi.com/licensing/entry/533038 (last visited Mar. 14).

${ }^{105}$ Crum, supra note 78, at 964.
} 
licenses. This increase in the number of licensed sampling artists may offset the decrease in fees per sample described above.

The stronger argument against the blanket license system is that it will take too much control away from copyright holders. In a blanket license system, copyright holders won't be able to say "no" to potential sampling artists. This is not a problem as long as samplers are using the copyrighted material for valid sampling purposes: samplers should be free to build on prior works as long as they are not violating copyright policy. However, the nature of a blanket license may eliminate some of the oversight and scrutiny that is built into the current system, in which each sample has to be cleared on an individual basis. This could lead to an environment where bad faith sampling and outright theft, or piracy, is rampant.

To illustrate the possible dangers of such a system, I will draw on some examples from the current music industry. In 2006 the electronic music duo Crystal Castles was accused of stealing beats from lesser known chiptune artists, who make music inspired by videogame soundtracks. ${ }^{106}$ Similarly, platinum hip hop producer Timbaland has been accused of unlicensed sampling from multiple obscure (at least to U.S. listeners) foreign musicians over the course of his career. ${ }^{107}$ Under the current copyright system, both Crystal Castles and Timbaland could have

${ }^{106}$ Gameboy Genius, Crystal Castles and Chip Music Copyright Infringements, http://gameboygenius.8bitcollective.com/wordpress/2008/05/06/crystal-castles-and-chip-music-copyrightinfringements/ (last visited Mar. 14, 2009).

${ }^{107}$ Nolan Strong, Rappers Jay-Z, Timbaland, Sued Over 'Big Pimpin' Melody, ALLHiPHop, Sept. 4, 2007, http://allhiphop.com/stories/news/archive/2007/09/04/18531856.aspx (last visited Mar. 14, 2009); Elizabeth Goodman, Is Timbaland a Thief?, ROLLING STONE, Jan. 18, 2007, http://www.rollingstone.com/rockdaily/index.php/2007/01/18/is-timbaland-a-thief/ (last visited Mar. 14, 2009)(allegations regarding 2006 song, "Do It"). It is important to note that the unlicensed sampling undertaken by Crystal Castles and Timbaland has been widely characterized in the media as "theft" or "beat jacking" while unlicensed sampling by Girl Talk has been widely characterized as innovative and legitimate. See, e.g. Greg Kot, Engineer Engages in Giddy Girl Talk, CHICAGO TRIBUNE, Dec. 29, 2006, available at http://archives.chicagotribune.com/2006/dec/29/news/chi-0612290089dec29 (“[Girl Talk's music] is legit and deserves to be heard"]). When viewed from a distance, these divergent characterizations seem incongruent and 
paid for licenses to use the beats they allegedly stole. On the other hand, the copyright holders of the original works could have refused to grant licenses.

Although a copyright holder does not need any reason for refusing to license his or her work, there are often valid reasons why an artist may decide to do so. Considering the above examples, it is easy to imagine that when a licensee uses a sample from a lesser known artist's work, the use by the more popular licensee (such as Crystal Castles or Timbaland) could eclipse the lesser known work, devaluing its potential market share. The copyright holder in this situation may therefore validly refuse to license the work for fear of being commercially overshadowed by the more popular artist. But under a blanket license system, the copyright holder in this situation would not be able to refuse the more popular licensee. Although some have theorized that a blanket license system would encourage sharing and creativity among artists by loosening the restraints on sampling, ${ }^{108}$ it is likely that such a system would become a tool by which popular artists could efficiently and legally co-opt the work of lesser-known artists. In the long run, this environment would probably lead to reduced creativity among artists. For example, in the chiptune community mentioned above, there are currently websites devoted to sharing member-created music. ${ }^{109}$ Crystal Castles allegedly lifted beats from one of these websites, prompting outrage and concern among chiptune musicians. ${ }^{110}$ A blanket license system authorizing established artists like Crystal Castles to take beats from such a website would

unfair to artists like Crystal Castles and Timbaland. But, there are some crucial differences between the artists' sampling practices, which explain the discrepancy. First, Crystal Castles and Timbaland hid the identities of the artists they sampled and presented the sampled portions as their original creations. Girl Talk, on the other hand, has always made it clear that he is sampling other artists. In fact, Girl Talk's music is only successful if his listeners recognize the sources of his samples. Second, Crystal Castles and Timbaland seemed to appropriate the sampled material to avoid the task of coming up with new material. Girl Talk, on the other hand, uses an amalgamation of samples to create something completely new. It is the difference between photocopying a page from a magazine and creating a collage made up of hundreds of images clipped from magazines.

${ }^{108}$ Crum, supra note 78, at 968-69; see also Lessig, supra note 101.

109 8bitcollective, http://8bitcollective.com/.

${ }^{110}$ Gameboy Genius, supra note 106. 
probably make members of the chiptune community think twice before posting their newly created beats. Such a system would encourage protectionism and secrecy, would discourage sharing, and would decrease creativity among both up-and-coming and established sampling musicians.

One possible solution to these kinds of problems would be legislative language stating that the kind of sampling involved in the Timbaland and Crystal Castles situations is not protected under a blanket license. But because sampling cases are so fact sensitive, a bright line rule determining when a sample comes under the blanket license and when it does not would probably be impossible to draft. The only way to really distinguish valid samples from invalid samples in this situation would be something like the fair use test, which would weigh factors to measure whether the use of each sample is transformative. Grafting a fair use-style test onto a blanket license system, however, would take away much of the predictability that makes a bright-line Bridgeport-style rule attractive. Although there would still be a bright line between those who purchase a blanket license and those who do not, a blanket licensed sampling artist, under the guise of a fair use style test, could never feel absolutely safe from an infringement claim. Presumably, parties under such a system could still contract for licenses over specific samples, and many artists would probably to do so in order to ensure the security of their licenses. At that point, the system would look similar to the current copyright system, except that sampling artists would be required to pay a license fee just to have the opportunity to invoke a fair use-style defense. 
For the above reasons, a blanket licensing system is not a viable solution in the sampling context. An expansion of the current fair use doctrine, however, may avoid some of the problems with a blanket license system.

\section{B. APPLICATION OF FAIR USE TO GIRL TALK}

\section{Purpose and Character of the Use}

In Campbell, the Supreme Court held that parody is a valid fair use purpose in the context of sampling. ${ }^{111}$ Gillis may have a strong argument that his sampling constitutes parody, but this depends partly on the artist that claims copyright infringement and the particular sample in question. For example, on the song "Smash Your Head" from Girl Talk's album Night Ripper, Gillis samples about a minute of Elton John's song “Tiny Dancer” and overlays this sample with a portion of the rap vocals from Notorious B.I.G.'s "Juicy." Although the two songs come from vastly divergent musical genres, the pairing is surprisingly powerful, prompting many reviewers to cite this passage as one of the album's highlights. ${ }^{112}$ Part of the passage's success derives from the juxtaposition of the romantic, somewhat quaint sentiments of "Tiny Dancer" with the gritty urban realism of "Juicy." While Elton John sings about an embrace with his lover ${ }^{113}$, Notorious B.I.G. recounts the unsavory details of life before he became a famous rapper. ${ }^{114}$ This juxtaposition is similar to that in Campbell, in which the rap group 2 Live Crew created a parody by altering the romantic lyrics of Roy Orbision's "Pretty Woman." The Court in Campbell

\footnotetext{
111510 U.S. at 579.

112 See Ryan Dombal, Album Review: Girl Talk, “Feed the Animals," PiTCHFORK, June 27, 2008, http://pitchfork.com/reviews/albums/11937-feed-the-animals/ (last visited Mar. 14, 2009).

${ }^{113}$ Elton John, Tiny Dancer, MADMAN ACROSS THE WATER (UNI Records 1971) (describing a love affair with the lyrics "Hold me closer tiny dancer/Count the headlights on the highway/Lay me down in sheets of linen/You had a busy day today").

${ }^{114}$ NotORIOUS B.I.G., Juicy, READY TO DIE (Bad Boy Records 1994) (describing the life of a rapper before his career with the lyrics "Born sinner, the opposite of a winner/Remember when I used to eat sardines for dinner").
} 
described the parody as a "comment on the naiveté of the original of an earlier day, as a rejection of its sentiment that ignores the ugliness of street life and the debasement that it signifies." 115 Gillis could argue that the juxtaposition of samples on "Smash Your Head" is a comment on the romantic naiveté of Elton John's song and that Gillis is therefore engaging in parody. Much of Girl Talk's music contains these kinds of juxtapositions, contrasting the romantic, idealistic sentiments of one work with the more realistic, gritty sentiments of another. So, this parody argument could be applied in defense of many of the samples Gillis uses.

However, Gillis' work does not fit neatly into every definition of parody presented by the Court in Campbell. The Court considered several definitions of parody, including: "a 'literary or artistic work that imitates the characteristic style of an author or a work for comic effect or ridicule." 116 The underlying facts in Campbell involved a hip hop song that ridiculed the material it sampled. ${ }^{117}$ But, continuing to use the Elton John and Notorious B.I.G. example, it seems inaccurate to say that Gillis ridicules either "Tiny Dancer" or "Juicy." Girl Talk's song is successful because "Tiny Dancer" and "Juicy" seem to blend together perfectly, casting each other in new light, but never at the expense of either of the original songs. Additionally, Gillis has stated that he is a fan of all the music he samples. ${ }^{118}$

But the Campbell Court went on to expand the definition of parody for the purposes of fair use, excluding the "ridicule" element. Parody, according to the Court, is "the use of some elements of a prior author's composition to create a new one that, at least in part, comments on

\footnotetext{
115510 U.S. at 583

${ }^{116} I d$. at 580 (quoting the AMERICAN HERITAGE DiCTIONARY).

${ }^{117}$ Id. at 583 .

${ }^{118}$ Sam Ubl, Interview: Girl Talk, STYlus MAGAZINE, Aug. 13, 2007, http://www.stylusmagazine.com/articles/interview/girl-talk.htm (last visited Mar. 14, 2009).
} 
that author's works." ${ }^{\prime 19}$ The parody's commentary must have a "critical bearing on the substance or style of the original composition." ${ }^{, 20}$ Although he does not criticize or ridicule the works he samples, Girl Talk's music could be considered commentary. By putting "Tiny Dancer" behind "Juicy," for example, Gillis heightens the nostalgia behind Notorious B.I.G.'s words and suggests a melancholy, which was not completely present in the rapper's original. Conversely the combination suggests a ruggedness and intensity that was not present in Elton John's original. This juxtaposition is representative of Girl Talk's music as a whole. Gillis's music is successful because it recontextualizes prior works, and in doing so creates new meaning, highlighting sonic textures and narrative themes which may have been obscured in the original songs. Because Gillis reinterprets the songs he samples, Girl Talk's music may reasonably be considered commentary on the substance or style of the original compositions. Therefore, Girl Talk may qualify as fair use parody.

Even if it does not qualify as parody, Girl Talk's music should still be considered transformative. As explained above, Gillis creates something new by combining and recontextualizing the old, which is exactly what a transformative work does. ${ }^{121}$ But whether a court finds that Girl Talk is transformative depends largely on the court's readiness to recognize this type of sampling as a creative art form. Take, for example, the divergent results in Campbell and Grand Upright. The sampling at issue in Campbell was not so different from the sampling at issue in Grand Upright. Biz Markie sampled some of the instrumentation from Gilbert O’Sullivan's “Alone Again, Naturally” and added new lyrics reflecting a more urban, less

\footnotetext{
119510 U.S. at 580 .

${ }^{120} \mathrm{Id}$.

${ }^{121} I d$. at 579 (a transformative work "adds something new, with a further purpose or different character, altering the first with new expression, meaning, or message").
} 
sentimental point of view. 2 Live Crew did the same thing with Roy Orbison's “Oh, Pretty

Woman." 122 Even though the facts of each case were similar, the results were wildly divergent.

The court in Grand Upright equated sampling with theft ${ }^{123}$ while the Court in Campbell

recognized that sampling does have artistic value and that 2 Live Crew's song could be a fair

use. $^{124}$

Because it is likely that a court will not be previously familiar with Girl Talk's work, the better Gillis is able to vocalize the idea and creativity behind his music, the more likely transformativeness will be found. The decision in Blanch v. Koons illustrates this concept and provides a strong boost to Gillis' claim that fair use applies to Girl Talk. ${ }^{125}$ Although the medium is different, Gillis' work is similar to Koons' work. The painting at issue in Blanch was a collage of several images (including women's feet and food) which Koons chose because they were the types of images that were ubiquitous in modern consumer culture. ${ }^{126}$ Gillis has described his work, which incorporates songs that are ubiquitous in modern consumer culture, as "sound collage." 127 In finding that Koons' work was transformative, the court seemed to rely heavily on Koons' own explanation of the meaning behind his art:

\footnotetext{
${ }^{122} \mathrm{Id}$. at 581-82.

123780 F. Supp. at 183 ("[t]hou shalt not steal).

124510 U.S. at 594.

${ }^{125}$ Record labels have been quick to take legal action against artists like Girl Talk in the past. Rock band U2's record label sued sampling group Negativland for its unauthorized use of U2's hit "I Still Haven't Found What I'm Looking For." Deuce of Clubs, Suits, Lawsuits and Art: Negativland Takes on the Man, PlanET MAGAZINE, July 4, 1995, available at http://www.deuceofclubs.com/write/negativl.htm. And when Dangermouse began distributing “The Grey Album," he received a cease-and-desist letter from EMI, which controls The Beatles' copyrights. Illegal Art, The Grey Album Legal Battle Summarized, http://www.illegal-art.org/audio/grey.html (last visited June 21, 2009). But pro-appropriation decisions like Blanch may partially explain why there have not any suits against Gillis thus far.

${ }^{126} 467$ F.3d at 255 .

${ }^{127}$ Brittany Salsbury, Still Not a DJ: An Interview With Sound Artist Girl Talk, F NeWSMAGAZINE, http://fnewsmagazine.com/2007-feb/still-not-a-dj.php.
} 


\begin{abstract}
Although the legs in the Allure Magazine photograph ["Silk Sandals"] might seem prosaic, I considered them to be necessary for inclusion in my painting rather than legs I might have photographed myself. The ubiquity of the photograph is central to my message. The photograph is typical of a certain style of mass communication. Images almost identical to them can be found in almost any glossy magazine, as well as in other media. To me, the legs depicted in the Allure photograph are a fact in the world, something that everyone experiences constantly; they are not anyone's legs in particular. By using a fragment of the Allure photograph in my painting, I thus comment upon the culture and attitudes promoted and embodied in Allure Magazine. By using an existing image, I also ensure a certain authenticity or veracity that enhances my commentary -- it is the difference between quoting and paraphrasing -- and ensure that the viewer will understand what I am referring to. ${ }^{128}$
\end{abstract}

If Gillis is able to coherently explain why his work requires the sampling of popular, instantly recognizable songs, a court will be more likely to side with him. And while one cannot presume to know what inspires Gillis' music, it does seem to make a strong statement about the universality of popular music, displaying the illusory nature of conventional music genres and labeling. Girl Talk has a big following, for example, in the indie music scene, where a sort of musical elitism exists among some fans, who pride themselves on finding and championing the most obscure music possible and spurning the mainstream and commercial. Many Girl Talk fans, for example, would not be caught dead listening Rick Astley, Hall \& Oates or Huey Lewis and the News. But all these artists are featured on Girl Talk's latest album, "Feed the Animals."129 Gillis challenges his listeners to think about music in new ways, to throw out the notion that certain songs are good and certain songs are bad, certain songs are cheesy and certain songs are cool. ${ }^{130}$ The music industry is organized for ease of marketing, with every artist listed under a specific genre. This genre-based categorization prompts music consumers to think in certain predictable patterns. Many music consumers in a certain demographic, for example, enjoy

\footnotetext{
${ }^{128}$ Blanch, 467 F.3d at 255.

${ }^{129}$ Andy Baio, Girl Talk's Feed the Animals: The Official Sample List, WAXY, Oct. 29, 2008, http://waxy.org/2008/10/feed_the_animals_official_sample_list/

${ }^{130}$ Gillis has said as much in interviews. PITCHFORK, supra at note 112, at 22.
} 
Notorious B.I.G. but would never purchase an Elton John album. Gillis seems to use his music to break down these boundaries, and to criticize the culture that has created them. And just as Koons needed to use the copyrighted photograph of a woman's legs to "ensure the viewer will understand what I am referring to," Gillis needs to use actual songs so that listeners will know he is making a point about the way people interact with popular music. If Gillis were to use conventional instruments to recreate the songs he samples, his point would lose much of its impact and he would probably confuse his listeners. It would be like a Shakespeare scholar rewriting lines of Hamlet instead of quoting the original.

Gillis may also argue that his music is a criticism of the current state of copyright law, and therefore protected as criticism under $§ 107$. On his most recent album, "Feed the Animals," Gillis samples 2 Live Crew, Roy Orbison and Metallica, ${ }^{131}$ all artists who have been involved, in some way or another, in the legal issues surrounding copyright. On his previous album, "Night Ripper," Gillis samples The Verve's "Bitter Sweet Symphony" and Elastica's "Connection," two songs which themselves have been the subject of copyright actions by prior artists. ${ }^{132}$ Gillis stated that he consciously chose the two "Night Ripper" samples because of the copyright controversy surrounding them. ${ }^{133}$ Gillis has demonstrated in interviews that he is familiar with the copyright issues surrounding his own music and the music industry generally. And by deliberately sampling the above artists, who serve as talismans representing the current restrictive state of copyright law, Gillis seems to be implicitly criticizing the current laws and arguing for a loosening of the restrictions. Just as the filmmakers in Lennon v. Premise Media

\footnotetext{
${ }^{131}$ Baio, supra note 129.

${ }^{132}$ The Verve used a sample of a Rolling Stones song and Elastica lifted a guitar riff from Wire. Baio, supra note 129.

${ }^{133} I d$.
} 
Corp. were justified in using the John Lennon song "Imagine" to criticize an atheist perspective, Gillis may be justified in sampling the above artists to criticize an overly restrictive sampling regime. ${ }^{134}$ At any rate, this criticism argument will be highly fact-specific and will only apply to a limited number of Girl Talk samples.

Finally, the fact that Gillis sells his music commercially does argue against finding a valid fair use purpose, but this should not be a strong impediment because almost all works that seek fair use protection will be of a commercial nature. ${ }^{135}$

\section{Nature of Copyrighted Work:}

The original works that Girl Talk samples are all creative, highly original works, and are therefore generally entitled to a higher level of protection than factual works or compilations. ${ }^{136}$ In the parody context, however, this factor is of little help because "parodies almost invariably copy publicly known, expressive works." ${ }^{137}$ So, if Girl Talk's music is found to be parody, then the fact that he samples creative works will not be a significant factor against fair use. If a court finds that Girl Talk's music is not parody, but that it is transformative nonetheless, then the same analysis the Campbell Court applied to parody should apply to Girl Talk's music. Although it may not be parody, Girl Talk's music, and mashup music in general, "almost invariably [copies] publicly known, expressive works." ${ }^{\text {138 }}$ Sampling popular, well-known songs is necessary for the success of Girl Talk's music. Therefore if a court finds that Girl Talk's music is transformative, then Girl Talk should not be penalized for sampling popular, well-known songs.

\footnotetext{
${ }^{134} C f$. Lennon v. Premise Media Corp., 556 F. Supp. 2d 310, 322 (S.D.N.Y. 2008).

${ }^{135}$ Campbell, 510 U.S. at 584-85.

${ }^{136}$ See Campbell, 510 U.S. at 586; Stewart v. Abend, 495 U.S. 207, 237-38 (1990); Suntrust Bank v. Houghton Mifflin Co., 268 F.3d 1257, 1271 (11th Cir. 2001). .

${ }^{137}$ Campbell, 510 U.S. at 586.

${ }^{138} I d$.
} 


\section{Amount and Substantiality of Work Used:}

At first glance, the Harper \& Row "heart" of the work test seems to cut against Girl Talk because most of Girl Talk's samples use the most instantly recognizable portions of the underlying songs. ${ }^{139}$ However, in Campbell the Court found that because a parody's success almost always depends on the use of instantly recognizable portions of the original work, the amount and substantiality factor has diminished strength in the parody context. In this respect, Girl Talk's music is similar to parody. Girl Talk's music, and mashup in general, is not successful unless the listener realizes that multiple popular songs have been combined to make a new composition. The excitement of listening to Girl Talk's music is recognizing the original songs that are being sampled while simultaneously hearing them in a new context. If Gillis were to sample unrecognizable portions of the original songs, much of this excitement would be lost. Girl Talk's music, therefore, like parody, depends on the use of highly recognizable portions of previous works. So if Girl Talk's music represents a valid fair use purpose, then Girl Talk should not be penalized for using substantial portions of the original songs.

In situations where Girl Talk's use is so insubstantial that the "average audience would not recognize the appropriation" then the de minimus defense (that the taking was too small to constitute an actionable infringement) may be applicable. ${ }^{140}$

\section{Effect on the Market for the Original}

\footnotetext{
${ }^{139} 471$ U.S. at 564-65 (quoting the district court opinion, 557 F. Supp. 1067, 1072 (S.D.N.Y. 1983)).

${ }^{140}$ See, e.g., Newton, 388 F.3d at 1193 (accepting de minimus defense when sampling artist acquired sound recording copyright but failed to acquire composition copyright); Fisher, 794 F.2d at 434 n.2; but cf., Bridgeport Music, Inc., 410 F.3d at 801-02 (6th Cir. 2005) (rejecting de minimus defense when artist failed to acquire sound recording copyright).
} 
While the market for certain artists that Girl Talk samples (Kenny Loggins, for example) may overlap very little with the market for Girl Talk music, the market for other artists (Lil' Wayne, for example) will have greater overlap. Consequently, this element is extremely fact specific, depending on the artist bringing the infringement claim.

Generally, however, Girl Talk does not seek to compete with the original samples he is using. His music truly does not fit into any current genre of mainstream music and it is unlikely that music consumers who are interested in buying an original song that Girl Talk samples will turn to Girl Talk as a substitute. As I have explained above, customers do not buy Girl Talk albums because they want to hear any of the particular samples in isolation, but because they want to hear how the samples are combined into a new whole. One may argue that Girl Talk impacts the derivative market for remixes of the original songs, just as 2 Live Crew's use possibly impacted the market for a rap version of "Pretty Woman." However, Girl Talk's music is not really anything like a traditional remix, which usually involves grafting a new beat or melody onto a pre-existing song. Girl Talk is more aptly described as "sound collage" than remix, so Girl Talk is not likely to encroach on the derivative market for remixes.

\section{CONCLUSION}

Girl Talk's music provides an example as to why the current fair use doctrine, despite its faults, is superior to a bright line test for copyright infringement in the sampling context. The uncertainty and fact specific nature of $\S 107$ is necessary because every fair use situation is different and the value of each creative work should be measured independently. We can't predict how technology will change music, so more fair uses may manifest in the future. The 
flexibility of the fair use doctrine will allow the law to adapt to these changes in technology and society. 